\title{
Products Liability: A Commentary
}

\author{
Grant Gilmore†
}

My initial reaction, when I was invited to comment on Professor McKean's paper, ${ }^{1}$ was one of blank astonishment, since I could think of no lawyer in the United States-indeed, in the free world-less qualified than myself for such an assignment. In speculating on what the committee on arrangements could have had in mind the only plausible explanation I have been able to come up with is this: it was decided that the Conference would be enlivened by a contribution from a lawyer who knew nothing-and was known to know nothing-either about economic theory or about current legal trends in what has come to be called Products Liability. In preparing to discharge the assignment, I could, of course, have undertaken a crash program of reading myself into some degree of familiarity with at least the legal aspects of the problem. I concluded, however, that such a course was not desirable: I would, had I followed it, have been derelict to the trust which the committee reposed in my ignorance. My function is evidently to comment, in a childlike fashion, on these mysteries-more or less, it may be, like the little boy who, rightly or wrongly, cried out in mid-procession that the Emperor had no clothes on.

\section{Ignoramus igitur:}

Professor McKean evidently feels that the bulk of the legal literature which has been devoted to Products Liability-in stupefying quantity during the past ten years-has been uncritical. The legal literature, indeed, reminds him of the old story about the six blind men who were attempting, under obvious difficulties, to determine what the elephant was really "like."2 I must say that I had never thought that the point of the story was that the blind men were being uncritical: on the contrary they were putting forward a series of rational, indeed sophisticated, hypotheses to explain the mystery which confronted them. If they had gone on dealing with the elephant,

† Harry E. Bigelow Professor of Law, The University of Chicago.

1 Products Liability: Trends and Implications [cited throughout this Symposium as McKean].

2 McKean text preceding note 125. 
the hypotheses which, in the light of experience, turned out to work poorly would no doubt have been discarded in favor of the hypotheses which produced better results. It is true that they failed to see the elephant whole: which of us ever does see his particular elephant whole? We can do a great deal more harm by persuading ourselves that we have penetrated to the truth of the matter than we can by accepting the uncomfortable fact that the best we have to go on are working hypotheses which may perfectly well be rooted in error.

Professor McKean suggests that clarity of thought will be promoted if lawyers and judges, instead of concentrating on such fuzzily defined or undefined or perhaps undefinable concepts as "fairness," "equity" and "justice," take into account the presumable economic effects of the various possible schemes of loss allocation on costs, prices, output and the use of resources. With greater clarity of thought, one would assume, it will become possible for us to shape the law, through better judicial opinions or through statutory reform, in ways that will be, in some sense, more effective, more satisfying-perhaps, in the last analysis, more in accord with our instinctive and irrational feelings of "fairness," "equity" and "justice." But it is just at this point that I have the greatest difficulty with Professor McKean's paper: having, by his remarkable analysis, immeasurably clarified our thought, he does not seem to have any convictions or even any particularly strong feelings about what we should do next. Of course, what we should do next-how shall this case be decided? how shall that statute be drafted?-is the question which lawyers-as legislators, as judges, as advocates, even as law professors-are professionally required to answer-and the answer must be provided even though the one thing that is clear as crystal is that we do not know enough to be sure, or even reasonably confident, that the answer provided is the correct answer or even one of a possible range of correct answers or at least not demonstrably the wrong answer.

It may be that there is an undercurrent in Professor McKean's paper to this effect: since "in the real world the implications of liability assignment," when analyzed in the light of the best economic theory, "are often complex and uncertain," nothing-to stop where we are-at least until our tools of theoretical analysis have been improved to the point where we can clear up the complexities and uncertainties of the real world. Perhaps I misread Professor McKean; perhaps he would not have us stop where we are; but let us assume for the sake of the argument that he-or some of his colleagues on the economic side-would. Why on earth should

3 McKean text at note 142. "Often," in the passage quoted, seems to mean "always." 
we stop at the point which we happen to have reached in 1969? It seems to be anyone's guess whether we are better or worse off than we were in 1919 or 1869: what we have gained on the swings we may have lost on the roundabouts. If we are at large on an uncharted sea and the one thing we can be sure of is that we have not yet reached safe harbor, we might just as well-at least just at well-continue the voyage: something good might turn up. In the second place, it is entirely obvious that we are not going to stop where we are. If motion is the law of life-or the life of the law-it is pointless to counsel immobility. The only status we know of is the status quo ante; we will never return to it but, if we did, we would discover that it too was as fluid and evanescent as any dream.

I take it that everyone-even, after some initial hesitations, Professor Calabresi4-accepts as true the "theorem" ascribed to my colleague, Professor Coase: ${ }^{5}$ that if transaction costs were zero and if all exchanges were voluntary-that is, not coerced-it would not matter how the legal rights or liabilities were initially assigned for economic purposes. In the context of this discussion, it would make no difference whether the purchaser (or user) or the manufacturer was liable for injuries or other losses resulting from, or caused by, the use of manufactured goods. At least, it would make no difference from the viewpoint of economic analysis: it would have no effect on resource allocation, nor, if I follow the argument, output. The assumptions which underlie the Coase theorem are, as Professor McKean puts it, "fairly heroic": transaction costs are not zero, there are always some costs of this type, in many instances they may be large and it will never, I assume, be possible to predict in any given case how large they will be or even to tell, after the event, how large they were in fact; nor are exchanges voluntary or non-coerced, certainly not all of them are and it may be that the truly voluntary exchange has become an almost extinct species in this all too real world in which no man is an island and each of us has become his brother's keeper.

Nevertheless, we are told, "it pays [us] to understand the oversimplified situation before trying to make judgments about the more complex ones."6 This would be true, I should think, if we could move by easy stages from the simple to the complex and if the complex, when we arrived at it, was recognizably of the same family as the simple model. It would not be true if there was simply no relationship

1 See McKean note 142 .

5 See McKean text following note 96.

6 McKean text following note 98 . 
that could be perceived between the two. In such a case the only conclusions that could be drawn from a comparison of the simple model with the complex reality (so far as that could, in any case, be accurately described) would be false-or, if true, would be so by the purest of accidents. Insofar as we put any store by-or allow our thinking to be influenced by-the Coase theorem, it predisposes us (emotionally or, perhaps, spiritually) to feel that the secular movement which has seen a notable expansion of the liability of manufacturers toward the users of their goods has been a great waste of everyone's time. If we make certain assumptions (the assumptions do not hold true in the real world but let's make them anyway), we can prove that it makes no difference, from an economic point of view, whether manufacturer or purchaser bears the liability-and of course no one can prove that "fairness," "justice" or "equity" is better served one way or the other. To the extent that our theoretical demonstration conditions our thinking about the real world (as it is meant to do and as of course it does), it leads us toward the conclusion that we would have done better not to have allowed the shift in liability to take place at all and that we should in principle oppose any further movement in that direction. That is, if we accomplish nothing -or nothing good-by changing the law, we should not change it. There is obviously much to be said, from the point of view of social or political theory, for stability in the law. Any change in the law is an evil, justifiable only if it is a necessary evil. (In another sense, we do not, by our conscious deliberate act, ever "change the law." The law changes itself, in response to mysterious and largely unperceived forces, of which we can take account only by hindsight. We are perhaps least in control when we fancy ourselves-as, say, the draftsmen of a new codification-to be the masters of all we survey.)

Thus, to the extent that we make use of the model hypothesized by the Coase theorem in making judgments about what we should do in the real world, the exercise leads us to conclude that we should do nothing; we should go no further; we should stop where we areeven if it is impossible for us to return to the golden age which lies somewhere in the past. This seems to be, as I have already said, the ultimate counsel that Professor McKean has for us. I see no relationship-whether it is described in terms of progression from the simple to the complex or in any other way-between Professor Coase's world in which there are no transaction costs and all exchanges are voluntary and a world in which there are always transaction costs and few, if any, exchanges that are voluntary. I am not persuaded by the 
economic analysis to say to the world: "Stop"-even if I thought that was a sensible thing to say to a world so irrevocably caught up in its gravitational system. Nor am I persuaded that we would all be as happy as larks if we could somehow get back to Winterbottom $v$. Wright ${ }^{7}$-although $I$ hasten to add that I am sure that Winterbottom was quite as sensible a case in England in 1842 as Goldberg v. Kollsman Instrument Corp. ${ }^{8}$ was in New York in 1963. It may be that what had changed between 1842 and 1963 was not so much the law as the societies which the law reflects.

In connection with the point that most cases-perhaps all casesare sensibly, or even "correctly," decided as of their own time and place, I will indulge myself in a brief digression on a landmark of the common law which takes us back two centuries before Winterbottom v. Wright-a case called Chandelor $v$. Lopus, which was decided by the Exchequer Chamber in 1625. $\mathrm{A}$ goldsmith had sold for $£ 100$ a stone which he "affirmed" to be a bezoar. The stone turned out not to be a bezoar. The disappointed buyer, who had presumably paid the price for a true bezoar, brought an action to recover damages for, as we should say, breach of warranty. Judgment for the goldsmithseller: he had merely "affirmed" that the stone was a bezoar without "warranting" it to be one-wherefore the buyer's action did not lie. For several hundred years the case has been cited, with approval or with scorn, as illustrative of the extremely narrow scope of liability which seventeenth century law placed on sellers for the quality of the goods they sold.

The report of the case does not bother to explain what a bezoar was-presumably everybody knew what a bezoar was, just as we all know what a diamond is. It occurred to me one day, in thinking about the case, that I for one had no idea what a bezoar might be. The new Oxford Dictionary proved to be illuminating. A bezoar (or "bezar") was, descriptively, "a calculus or concretion found in the stomachs of some animals, chiefly ruminants, formed of concentric layers of animal matter deposited round some foreign substance, which serves as a nucleus." That explains everything except why a bezoar would have been worth $£ 100$ in the early 17 th century. The true value of a bezoar, it appears, lay in its magic or, as we should say, medicinal properties: application of the bezoar to a diseased part of the body cured the disease. "Everything that frees the body of any ailment,"

7152 Eng. Rep. 402 (Ex. 1842). The case is set out in McKean text at note 6.

812 N.Y.2d 432, 191 N.E.2d 81, 240 N.Y.S.2d 592 (1963); McKean text at notes 52-53.

979 Eng. Rep. 3 (Ex. 1625). 
it was said, "is called the Bezoar of that ailment." And the East India Company had reported in 1618 that: "On the island of Borneo, diamonds, bezoar stones and gold might be obtained."

Now that we know more about bezoars than we did, we may begin to wonder whether our initial reaction to the holding in Chandelor $v$. Lopus was, historically, correct-or even relevant to the case. It was generally known that there were true, or magic, bezoars. It must also have been a matter of common knowledge that it was extremely diffcult, if not impossible, to tell a true bezoar from a false one. And no doubt the attitude of the user counted for something: if I believed in my bezoar it might indeed preserve me from the plague while the same stone in the hands of a skeptical rationalist would be worthless. Under such circumstances a court might hesitate to impose liability on a seller who had merely said that, to the best of his knowledge, he believed (or affirmed) the stone to be a bezoar, but did not warrant it. It may be that the 17th century concept of liability was not as narrow as we have supposed it to be. This digression, at all events, goes to the point that law cases-and rules of law-are really not abstract propositions, although we like to phrase them, and talk about them, as if they were. The cases and the rules-and indeed the codifying statutes-are merely particular responses to particular states of fact (assumed to be true whether or not they are). The law is, and I dare say always will be, ad hoc and ad hominem to a fault.

Just as everyone accepts the Coase theorem, so everybody accepts the proposition which Professor McKean develops in his paper: that in the course of the past hundred years there has been a notable expansion of seller's (and particularly manufacturer's) liability toward the buyers (or users) of goods sold. The allocation of the risks inherent in the use of the goods has tended to shift from the buyer-user to the seller-manufacturer.

Professor McKean cautions us that "the magnitude of the shift in liability assignment so far has not been dramatic. The main thing that has happened lately is a further modest increase in the probability that injured persons will be compensated by the producer."10 As he points out, no court has ("so far") imposed truly strict liability-that is, allowed recovery where all that the injured plaintiff proved was that his injury resulted from his use of the goods. To date even the most "advanced" or "humanitarian" courts have insisted that the plaintiff prove, additionally, that the goods, whose use caused the injury, were, in some sense, "defective." And "defective," as Professor McKean argues, can be taken to mean approximately the same thing that "fault"

10 Mckean text following note 79. 
or "negligence" meant in the old cases-so that there has been at most a "modest," not a "dramatic," realignment of liabilities.

And yet I am inclined to wonder whether there may not be more in the terminological switch from "negligence" to "defective" than meets the eye. A rose, we have been told on good authority, by any other name would smell as sweet. And yet, if we start calling a rose by some other name, something important has obviously happened: our conception or perception of the rose has fundamentally changed-otherwise we would still call it a rose. We now think differently about what we used to call roses-which may affect not only ourselves but also the roses (or ex-roses). Quite possibly the rose will go on smelling as sweet as it does only so long as we go on calling it a rose. Professor McKean is obviously in the right when he says that "defective" can be made to bear the same freight of meaning that "negligence" used to bear. But I am not at all sure that things will work out, or have been working out, that way: if that was in the cards, I think we would have gone on saying "negligence."

I will, therefore, mildly object to Professor McKean's downgrading of the revolution: there has been not a "modest" but a dramatic shift in the allocation of liability. Whether the shift has been modest or dramatic is irrelevant to Professor McKean's argument, on his own premises. But it is the prerogative of any commentator to switch the premises, without warning, which is what I now propose to do.

"Products Liability" is a term that has come into use only in recent years. Lawyers used to talk, more cumbersomely, of liability for breach of warranty, without bothering to make clear whether they were talking about liability in contract or liability in tort. Warranty law indeed has always had one foot in contract and the other foot in tort and this ambiguous straddle over the great legal divide has done a great deal to keep the legal discussion open-ended. Whenever a particular state of doctrine on one side or the other of the divide has seemed to present a roadblock to further progress, ${ }^{11}$ it has been possible to get around the obstacle by pointing out that the action is really in tort (if the roadblock is on the contract side) or really in contract (if the roadblock is on the tort side). ${ }^{12}$ In days when the courts took the concept of "negligence" more seriously than they do now, the escape from carrying the burden of proof on that issue was to emphasize the absolute promissory nature of contract warranties; in the course of that demonstration there developed the vast and intricate

11 "Progress"-i.e., further expansion of the seller's warranty liability. The movement was evidently thought to be "progressive" whether, in fact or theory, it was so or not.

12 This idea is developed in Gilmore, Law, Logic and Experience, 3 How. L.J. 26 (1957). 
structure of the law of implied warranties. In this century the roadblocks have been located mostly on the contract side-the defenses of privity of contract, of disclaimer, of the plaintiff's failure to give timely notice of the defect-so that we have become accustomed to thinking of tort as providing the escape route. But if the going were to become rough in tort-if, for example, by judicial reversal or statutory reform, a meaningful concept of fault as a condition of recovery in the tort action were reintroduced-we would no doubt revert almost instinctively to emphasizing the contract nature of the action.

It will be noted that "Products Liability" identifies a field of law much more narrowly circumscribed than what would be included if we followed the older usage and said "liability for breach of warranty." The warranty concept covers transfers not only of goods but of real property and, for that matter, negotiable instruments and intangible claims. Even if we restrict ourselves to goods, the concept covers not only the products of a complex technology but, indifferently, the farmer's horse or crop of hay or stock of firewood. And throughout most of our history we have not differentiated, as to warranty liability, between the simple and the complex. The coming into use of such a term as "Products Liability" suggests that we are beginning to make such a differentiation-or at least that those who use the term think that we ought to make such a differentiation. The liability of one who furnishes a "product"-which obviously means a complex artifact-should be thought about differently from the liability of one who furnishes a simple thing like a horse or a haystack or a cord of firewood.

This identification of a new field of law, by way of narrowing or subdividing a previous, broader field, is a recurrent phenomenon in our legal history. For example, there are no references, much before 1800 , to a law of sales of goods, conceived as a branch of law separate and distinct from the law of sales of property in general. The new field organized itself, with astonishing rapidity, within half a century following the Industrial Revolution of the 18th century. In much the same way the law of insurance in the 19th century and labor law in this century split off, or were divorced from, the undifferentiated law of general or simple contracts. The appearance of a new "field" or "branch" of law is always a matter of great interest: it teaches us that something new and important has taken place and gives us, as it were, a new fix on the elephant. Thus the recent surfacing of something called Products Liability, with the suggestion that the time may have come for differentiating the law of complex artifacts from the law of simple goods, is something with a claim to be taken seriously. And, 
as the spate of law review articles over the past ten years shows, it is being taken seriously.

And yet, in the understandable excitement of realizing that we may have come on something new-Products Liability-we are, I think, in danger of putting ourselves in blinkers by concentrating too narrowly on what appears to be going on in our newly discovered landfall. I will suggest, at all events, that we can profitably broaden our discussion. I will put forward this proposition: that the expansion of seller's or manufacturer's liability for the use of goods manufactured or sold is by no means an isolated development in the newly discovered area of Products Liability; a comparable expansion of liability has been going on, notably since 1900 , over the whole spectrum of our law of civil obligations, alike in contract and in tort.

This proposition obviously does not rise to the dignity of a theorem: I could not prove it if I were, like Gibbon, to scribble on for the rest of my natural life. But let us assume, arguendo, that my proposition expresses at least one of the many possible faces of truth-that what has been going on in Products Liability is merely a special instance of what has been going on over a much broader front. If that is so, we would be at fault, as lawyers or as economists, in dealing with the special instance as if it were an isolated, or isolatable, phenomenon. In trying to understand it or explain it or criticize it-or even clarify our thought about it-we should at least make an attempt to see it in the broader context.

In our legal system we have--largely as the result of historical accident-split the whole field of civil obligation into contract obligations and tort obligations. Essentially the distinction is that the typical contract obligation is one that was voluntarily assumed (or at least the transaction that gave rise to the obligation was voluntarily entered into) whereas the typical tort obligation is one that was blundered or stumbled into through accident, negligence or fraud. The categories merge or blur at the edges: we have come to speak of a no man's land between contract and tort as quasi-contract although we might just as well have called it quasi-tort.

In most situations of this type we can identify an active and a passive party. In tort there is the tortfeasor and his victim. In contract there is typically one party who has undertaken to provide goods, services or whatever to another party whose only duty is to pay for what he receives. We will speak of performing parties (e.g., sellers) and paying parties (e.g., buyers).

Our law of contract is almost entirely a 19th century construct -there is little or nothing (except for some antiquarian embroidery) 
whose roots go back in time beyond the Industrial Revolution. Indeed the first authoritative formulations of our theory of contractual obligation came late in the 19th century, with Langdell, Holmes and Williston in this country and Pollock in England. These writers put together, from bits and pieces of then fairly recent case law, a comprehensive theory of contract in much the same way that the staff of a natural history museum might reconstruct a dinosaur from a tooth or two and a few odd scraps of bone. It is impossible not to conceive the greatest admiration for the ingenuity of their construction; it is equally impossible to escape the conclusion that they achieved their results by overstating their cases and by erecting monumental hypotheses based on the flimsiest substructure of evidence or fact. What came out was no doubt responsive to the spirit and ethos of the time: we get not only the governments but also the theories we deserve.

As we look back, the 19th century construct seems to have favored the active or performing over the passive or paying party to a degree that we now find difficult to comprehend. It may be that a society which had not yet learned to think of itself as affluent and in which the remembered threat of famine and scarcity still weighed more heavily on the mind of man than present visions of glut and abundance treasured any form of social action-particularly any form of action which would increase the aggregate production of manufactured goods. Such action should be encouraged in all possible ways-it received indeed, in addition to the unqualified blessing of press and pulpit, the weighty approval of the best, or at least the most respectable, economic theorists. One of the ways in which it was sought to be encouraged was by the prompt provision of a legal structure which cast the risks of enterprise or action on the passive recipients of its bounty and insulated the actor from the incidentally harmful consequences of his socially useful activity. ${ }^{13}$

During the past seventy-five years or so the legal rules and doctrines which successfully immunized actors or enterprisers from liability have been in process of breakdown. The process could, with equal facility, be traced on either the tort or the contract side. I shall, impressionistically and without any attempt to document my statements, describe some of the things that have been going on in contract during this century. (It may be that the contract developments are more im-

13 of course, in the light of the economic analysis, such an allocation of risks may have had nothing to do with encouraging action or increasing production. But if it is popularly believed that, as between $A$ and $B$, throwing the risks on $B$ will encourage $A$, then, assuming that society wants to encourage $A$, the risks will be thrown on $B$. Both $A$ and $B$, needless to say, usually share the popular belief. 
mediately relevant to the subject of this Conference than the comparable tort developments are, and in any event I am more familiar with their detail than I am with that on the tort side.)

Under the rules of offer and acceptance, as they came to be formulated in the late 19th century, no contractual obligation could be imposed until the last $i$ had been dotted and the last $t$ crossed. Courts, it was said, did not make contracts for the parties; the undotted $i$ or the uncrossed $t$ was fatal and the courts would do nothing about it. Nor was any duty recognized to deal fairly or in good faith with the other party during what may be called the pre-contractual period while negotiations are going on but the deal has not yet been worked out to its last detail. Until the contractual trap was sprung, I could lead you on and keep you in play as long as I wanted (or was able) to without coming under any liability to you if at the last minute I decided to cut you loose. And if, without the protection of a binding contract, you incurred expenses, in reliance on my presumed good faith, the resulting loss was yours, not mine. These rules, were, of course, stated as two-way streets: either party could take advantage of them. Factually it was the enterpriser, the performing party, who could manipulate the rules to his own advantage and delay binding himself while being in a position to spring the trap on the other party whenever he pleased.

Just as the rules made it extremely difficult to get into a contract in the first place, so they made it extremely difficult to escape from a contractual obligation once imposed. The rules of discharge, like the rules of offer and acceptance, were stated in terms of even-handed justice: nothing short of absolute impossibility or the act of God would discharge either party to a contract. The way this worked out, for example, between sellers and buyers, was this: buyers were never discharged, no matter how catastrophically the contract had turned against them, while sellers were discharged with great liberality. As to buyers: it is never impossible, the courts explained, to pay money. ${ }^{14}$ As to sellers: if the goods which the seller has contracted to sell are destroyed before they have been transferred to the buyer, or if the source of supply from which the seller expected to obtain the goods becomes unavailable, it is, "obviously," strictly impossible for him to perform the contract-wherefore he is discharged. ${ }^{15}$ And, some courts

14 See, e.g., Levy Plumbing Co. v. Standard Sanitary Mfg. Co., 68 S.W.2d 273 (Tex. Civ. App. 1933), a delightful case in which it appeared that the fact that all the banks in the country were closed (during the 1933 bank holiday) did not relieve a buyer from his obligation to pay on a particular day. In point of fact it might of course have been diffcult to raise the money; in point of law there was no impediment.

15 See, e.g., Howell v. Coupland, I Q.B.D. 258 (1876). The American cases were to the 
suggested, if the case is that the seller can still perform the contract but only at a cost greatly in excess of the contract price, there too he should be discharged on a theory of "economic impossibility."10

Damages for breach of contract, we have been told for a hundred years, are meant to be compensatory-no more, no less. What is compensatory? When a buyer breaches a contract, it is hard to imagine a case where the seller's damage claim can exceed the contract price; under 19th century sales law seller, on buyer's breach, was almost routinely entitled to recover the full price. ${ }^{17}$ When a seller breaches a contract, the losses which the buyer may suffer as the direct result of the breach need not be limited to the contract price and may largely exceed it. The whole structure of the 19th century damage law seems to have been dedicated to the proposition that the buyer should get no more than a token recovery. ${ }^{18}$ The buyer could almost never get the goods in any form of action; he was remitted to his action in damages and in that action what he was entitled to was the differential between the contract price and the (higher) market price at the time and place when the seller ought to have delivered them. For a buyer to recover any more than that differential was about as easy as it is thought to be for a camel to pass through the needle's eye. (Larger damages-for injury to person or property-were recoverable in the action for breach of warranty, but of course that action was cribbed, cabined and confined by the many available contract defenses that Professor McKean has described for us.)

I have briefly suggested three aspects of 19 th century contract doctrine which worked in favor of sellers against buyers or of performing parties against paying parties. At the cost of another dozen pages, I could add a dozen more examples-which, however, I will not burden you with. I should add that I have been describing the overt or received doctrines of the period. It is entirely possible to demonstrate, by a sophisticated analysis, that sometimes or frequently or even most of the time what the courts did in fact did not jibe with what they said they were doing. ${ }^{19}$ But, jurisprudentially, what the courts say

same effect, as were the later codifying statutes, English and American. See, e.g., UNIFORM SALES AcT $\S \S 7,8$.

16 Cf. Restatement of Contracts \& 454 (1932 version).

17 See Uniforar Sales Acr $\$ 63$. The pre-statutory law in such states as New York was even more favorably disposed to the seller's action for the price.

18 The opinion of Holmes, J., in Globe Ref. Co. v. Landa Cotton Oil Co., 190 U.S. 540 (1903), is a classical statement of this position.

10 To every rule there is a counter rule, or, in an alternative formulation, every rule is eaten up by its own exceptions. This phenomenon, like the ambiguity previously noted as to whether the warranty action lies in contract or in tort, does a great deal to keep the legal discourse open-ended. 
they are doing is at least as interesting as what they do--particularly when they say one thing and do another. That line of thought, however, would take us into uncomfortably deep waters and I will not further pursue it.

An observer of the current contract scene, as contrasted with the one I have been describing, could only conclude that a revolution must have taken place. Indeed, as we all know, a revolution has taken place and it would be surprising if it had not left its traces on our law of contract. The old offer and acceptance rules have quite broken down. Courts do indeed make contracts for the parties, dotting any number of i's and crossing any number of t's; they have indeed been directed to do so by statute. ${ }^{20}$ The idea of a pre-contractual duty of good faith and fair dealing has come to the surface; maybe it was there, hidden, all the time but now, for the first time, it is being talked about openly in the respectable columns of the Harvard Law Review. ${ }^{21}$ The old law of strict impossibility has given way to the so-called doctrine of frustration: if a party's purpose in entering into a contract has been "frustrated" by an untoward turn of events, he should be discharged. Under this approach buyers are now discharged quite as liberally as sellers ever were. ${ }^{22}$ While the seller's right to recover the price on buyer's breach has been severely cut back, ${ }^{23}$ the buyer's right to get the goods, on seller's refusal to deliver them, has been correspondingly expanded. ${ }^{24}$ And one of the most dramatic events of the past thirty years or so has been the rewriting of the law of damages in favor of buyers claiming large recoveries and the rapid development of the idea that reliance losses should be reimbursed even when they are incurred without the protection of a binding contract. ${ }^{25}$

The point of the foregoing discussion is that the same reversal of risks, which Professor McKean has documented in the Products Liability cases, has been going on all over the place. It has been, no doubt, all part and parcel of the great shift, so bitterly lamented in many

20 See, e.g., Uniforar Commercial Code \$§ 2-204 through 2-209.

21 See Kessler \& Fine, Culpa in Contrahendo: Bargaining in Good Faith, and Freedom of Contract: A Comparative Study, 77 HARv. L. Rev. 401 (1964).

22 See Berman, Excuse for Nonperformance in the Light of Contract Practices in International Trade, 63 CoLum. L. REv. 1413 (1963). Professor Berman, who agrees that the rules of discharge have been liberalized or weakened, on the whole disapproves of the trend.

23 Compare Uniform Commerctal Code \& 2-709 with Uniform Sales Act \& 63.

24 Compate UNiform Commercial CoDE \& 2-716 with UNiform SAlEs ACT $\$ 68$. There is, however, much more to the argument than the two statutory sections suggest.

25 See Fuller \& Perdue, The Reliance Interest in Contract Damages, 45 YALE L.J. 52 (1936). Professor Fuller's remarkable article may have been influential in stimulating or accelerating this trend. 
quarters, from laissez-faire to the Welfare State and beyond. We falsify and distort our discussion if we isolate for analysis one particular ripple in the tidal wave-at least we falsify and distort if we end up arguing that our chosen ripple ought to have gone this way even though the rest of the wave went that way.

There is no point in arguing with a revolution. It may be that whatever can be pulled down ought to be pulled down; if it is no longer strong enough to withstand assault, it should be replaced by something that is. In this sense any successful revolution is self-justifying: by its success it has revealed the inadequacies of what it has replaced. We may have a romantic attachment to the old regime but we should not let it cloud our thought about present reality.

The Coase theorem, truly understood, may prove conclusively that all the changes which have taken place in our society since 1850 - or 1750 or 1650 -have been, from the point of view of economic theory, undesirable. The realization that this was so would sadden me but I would not see that much could be done about it or that anything should be done about it. I do not for a moment dispute or deny the great value of abstract theoretical analysis or the pure delight of engaging in it. I doubt that it gives us, or is meant to give us, guidance in handling real problems in the real world. It is entirely within the realm of possibility that the forces which have determined the shift in risk allocation which has been going on for the better part of a hundred years will cease to operate and that we will reverse our course or set out in a new direction never before dreamed of. But that, if it were to happen, would have nothing to do with the fact that we had at last learned to think clearly about what was going on. The wit of man is from the start overmatched by the weight of circumstance and, except in the simplest situations, thinking clearly and acting sensibly really have nothing to do with each other. 